\title{
AVALIAÇÃO DE PROCESSOS MECÂNICOS DE LIMPEZA DE CARIOPSES DE CANA-DE-ACUÚCAR E SEUS EFEITOS NA QUALIDADE
}

\author{
FLÁVIO FRANCO CÔRTE BRILHO
}

Orientador: HASIME TOKESHI

Dissertação apresentada à Escola Superior de Agricultura "Luiz de Queiroz", da Universidade de São Paulo, para obtenção do título de Mestre em Agronomia. Área de Concentração: Fitopatologia.

PIRACICABA

Estado de São Paulo - Brasil

Novembro, 1984 
ii.

A minha esposa e aos nossos pais DEDICO. 


\section{AGRADEC IMENTOS}

Externamos nossos agradecimentos a todos aquêles que direta ou indiretamente contribuiram para a realização deste trabalho, principalmente às seguintes pessoas e entidades:

- Ao Prof. Dr. Hasime Tokeshi pela orientação, interesse cientifico; a ele e esposa pela amizade e estímulo constan tes.

- Ao Engo Agro MS. Carlos Alberto Guedes Ribeiro pelo apoio e valiosas sugestões.

- Ao Eng@ Agro Dr. Sizuo Matsuoka, pela revisão e sugestões.

- Aos Professores do Departamento de Fitopatologia da ESALQ pelo apoio durante o curso.

- Ao IAA-PLANALSUCAR, em especial à Coordenadoria Regional Nordeste, pelo apoio, materiais e meios concedidos.

- A Cooperativa Central de Produtores de Açücar e Alcool do Estado de São Paulo, pela oportunidade de realização do curso.

- Aos Funcionários do Laboratório de Sementes da Coordenadoria Regional Nordeste pelo auxilio na condução dos experimentos. 


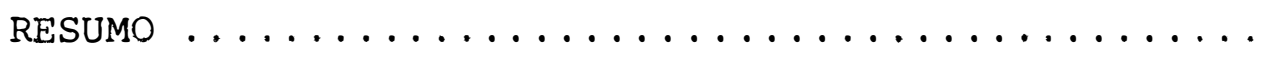
SUMMARY

1. INTRODUÇ $\widetilde{A} O$

2. REVIS̃̃O DE LITERATURA

3. MATERIAL E METODOS

3.1. Descrição da máquina de pré-limpeza dos cạ

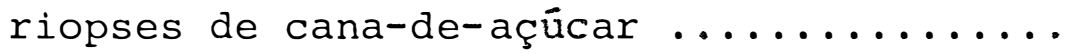
3.1 .1 . Motor $\ldots \ldots \ldots \ldots \ldots \ldots \ldots \ldots \ldots \ldots \ldots \ldots \ldots \ldots$

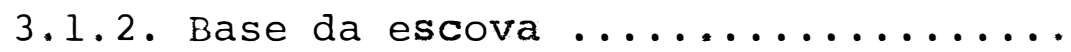
3.1.3. Câmara de prē-limpeza ........... 3.1.4. Fixador da câmara .............

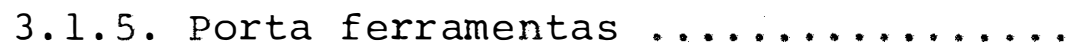

3.2. Escolha da superfície de fricção complemen

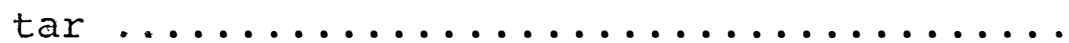

3.3. Eficiência dos tratamentos de pré-limpeza dos cariopses determinadas após ventilação e avaliadas pelas diminuições de volume e peso, pela porcentagem de germinação e indice de vigor $\ldots \ldots \ldots \ldots \ldots \ldots \ldots \ldots$ viie

$x i$ 
3.3.1. Eficiência dos tratamentos de pré-lim puza dos cariopses determinadas apōs a ventilação e avaliadas pela redução de volume $\ldots \ldots \ldots \ldots \ldots \ldots \ldots$

3.3.2. Eficiência dos tratamentos de pré-lim peza dos cariopses determinadas apōs a ventilação e avaliadas pela redução

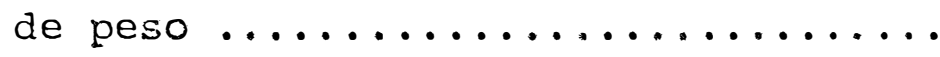

3.3.3. Eficiēncia dos tratamentos de pré-lim peza dos cariopses determinadas após a ventilação e avaliadas pela porcentagem de germinação ............

3.3.4. Eficiência dos tratamentos de pré-lim peza dos cariopses determinadas apös a ventilação e avaliadas pelo indice de vigor $\ldots \ldots \ldots \ldots \ldots \ldots$

3.4. Determinação do rendimento da mäquina de

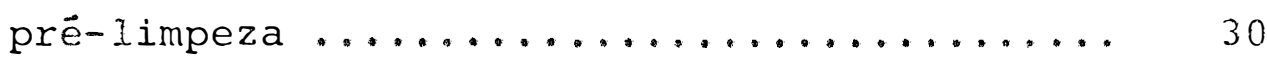

3.5. Sanidade de cariopses sem cascas e cascas apōs prē-limpeza e limpeza, e de cariopses com pêlo $\ldots \ldots \ldots \ldots \ldots \ldots \ldots \ldots \ldots$

4. RESULTADOS ......................... 
4.1. Escolha da superfície de fricção complemen-

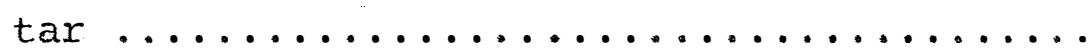

4.2. Eficiência dos tratamentos de pré-limpeza dos cariopses determinadas apôs a ventilaÇäo e avaliadas pela redução de volume ....

4.3. Eficiência dos tratamentos de pré-limpeza dos cariopses determinadas após ventilação e avaliadas pela redução de peso ..........

4.4. Eficiência dos tratamentos de pré-limpeza dos cariopses determinadas apōs ventilação e avaliadas pela germinação ............

4.5. Eficiência dos tratamentos de pré-limpeza dos cariopses determinadas apôs ventilação e avaliadas pelo vigor $\ldots \ldots \ldots \ldots \ldots \ldots \ldots$

4.6. Avaliação do rendimento dos processos de pré-limpeza $\ldots \ldots \ldots \ldots \ldots \ldots \ldots \ldots$

4.7. Sanidade de cariopses sem cascas e cascas após pré-limpeza e limpeza, e de cariopses

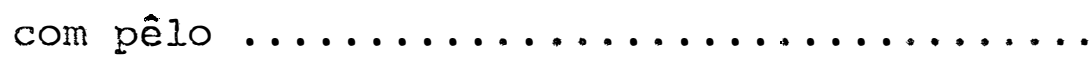

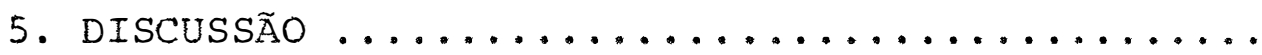

5.1. Escolha da superfície de fricçäo complemen $\operatorname{tax} \ldots \ldots \ldots \ldots \ldots \ldots \ldots \ldots \ldots \ldots$ 
5.2. Eficiência dos tratamentos de prë-limpeza dos cariopses determinadas após ventilação e avaliadas pela redução de volume ........

5.3. Eficiência dos tratamentos de pré-limpeza dos cariopses determinadas após ventilação e avaliadas pela redução de peso ..........

5.4. Eficiência dos tratamentos de pré-limpeza dos cariopses determinadas após a ventilação e avaliadas pela porcentagem de germina

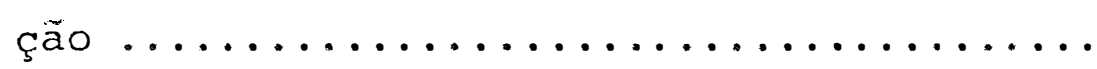

5.5. Eficiência dos tratamentos de pré-limpeza dos cariopses determinadas após a ventilação e avaliadas pelo vigor ..............

5.6. Determinação de rendimento da máquina de pré-limpeza ................... 46

5.7. Sanidade de cariopses sem cascas e cascas após pré-limpeza, e de cariopses com pêlo.

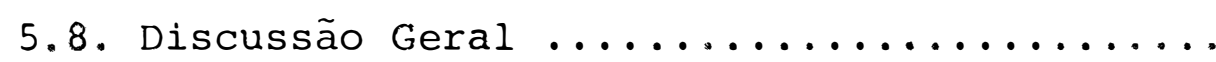

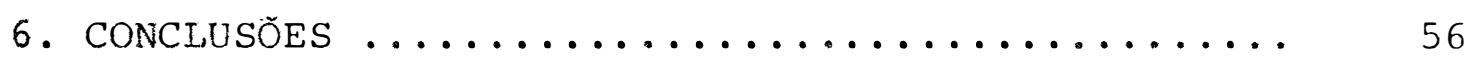

7. IITERATURA CITADA .................. 58 
AVALIAÇAO DE PROCESSOS MECANICOS DE LIMPEZA DE

CARI OPSES DE CANA-DE-ACDCAR E SEUS EFEITOS NA QUALIDADE

Autor: Flāvio Franco Corte Brilho

Orientador: Prof. Dr. Hasime Tokeshi

\section{RESUMO}

No programa de melhoramento genético da cana-de-açūcar desenvolvido pelo IAA-PLANALSUCAR vem se empregan do desde 1981 equipamentos de pré-limpeza e limpeza de cariopses de cana-de-açúcar por processo mecânico.

Como até o presente não havia sido feito nenhum estudo global sobre os beneficios gerados por esses equipamentós e processos, procurou-se quantificar a ação da prē-limpeza e limpeza com diferentes superfícies de fricção e tempos de operação, no peso, volume, germinação, vigor e sanidade dos cariopses que receberam beneficiamento parcial.

Os resultados obtidos indicaram reduções de $72 \%$ em volume, $68 \%$ em peso sem provocarem nenhum efeito prejudicial no vigor, na germinação e na sanidade dos cariopses. 
Dos resultados e discussões foram obtidas as seguintes conclusões:

a. as operações de pré-limpeza e limpeza de cariopses de cana-de-açücar utilizados nos programas de melhoramento pro porcionam economias substanciais no armazenamento dos mes mos e nos custos de obtenção de plântulas;

b. as reduções do volume de cariopses a serem armazenados possibilitaram a substituição de dispendiosas câmaras frí gorificas de volume aproximado a $20 \mathrm{~m}^{3}$ por congeladores domësticos de $0,5 \mathrm{~m}^{2}$;

c. a elevação da pureza física dos cariopses assim obtidos poderá aproximar os programas de seleção precoce para re sistência ao carvão da cana-de-açūcar aos altos níveis obtidos experimentalmente;

d. os equipamentos em uso no programa de melhoramento genéti Co do IAA-PLANALSUCAR são eficientes, pois a avaliação global de germinação, vigor, e sanidade dos cariopses trạ balhados não evidenciou injürias nos mesmos, proporcionan do somente benefícios;

e. o controle do teor de umidade dos cariopses que receberão 
. $\chi$.

pré-limpeza com a superfície de fricção complementar deve ser efetuado com precisão para evitar danos mecânicos. 
EVALUATION OF MECHANICAL BLOWING PROCESS OF SUCAR CANE CARYOPSES AND EFFECTS IN QUALITY

Author: Flāvio Franco Corte Brilho Adviser: Prof. Dr. Hasime Tokeshi

\section{SUMMARY}

The Brasilian National Sucarcane Breeding Program conducted by Sugar and Alcohol Institute has been using since 1981 the defuzzing and blowing equipments to improve caryopses quality of breeding material. Until now, no complete evaluation of benefits produced by the equipments and process in usage has been done.

The present research was set to measure the effect of defuzzing and blowing using different friction surface and running time on caryopses wheight, volume, germination, vigor and sanitation after partial cleaning operation. The results indicated reduction of 72 percentage in the volume and 68 perce-tage in wheight, whithout affecting the germination, the vigor and the sanitation. 
conclusions were inferred:

a. the application of defuzzing and blowing of sugarcane caryopses in the breeding program is giving high reduction in expenses of seed storage and seedling production;

b. the volume reduction of caryopses under storage turns possible the substitution of coustly 20 cubic meters deep frezing chamber for unespensive domestic freezer of 0.5 cubic meter;

c. the caryopses physical purity would improve the early screening method of sugarcane resistant to smut toward to the efficiency obtained experimentaly;

d. the equipaments in use by the Brasilian Sugarcane Breeding Program are efficient since the total evaluation of germination, vigor and sanitation of cleaned caryopses do not indicate any injure effect, only benefits;

e. the moisture control of caryopses must be accured to reduce injure level caused by the complementary friction surface. 


\section{INTRODUÇÃO}

A cultura da cana-de-açúcar no Brasil ocupa a ārea de 3,7 milhões de hectares e representa a maior fonte de matéria prima para a produção de açücar e álcool. Haven do O PROALCOOL se firmado como um programa de produção de energia renovāvel bem sucedido no paỉs, a importància da cana-de-açúcar deverá crescer à medida que as reservas mundiais de petróleo se esgotam forçando o uso de energia renovâvel. Para tornar O PROALCOOL mais competitivo no futuro e também para diminuição dos custos de fabricação do açũcar, há necessidade da obtenção de novos cultivares de cana-de-açúcar, adaptados às diferentes condições edafo-climáticas nas quais serão cultivados.

Nos trabalhos de melhoramento genëtico de cana-de-açūcar, após a produção e processamento dos cariop- 
ses (considerados aqui como espiguetas fërteis ou não), inicia-se a etapa de obtenção de plântulas, que apōs sucessivas seleções e testes poderão dar origem a novos cultivares. Nes ta etapa tem-se observado problemas de falhas de germinação, devido a presença de impurezas, fungos patogênicos e cariopses inferteis. Procurando solucionar os problemas de obtenção de plântulas, o Departamento de Fitopatologia da Escola Superior de Agricultura "Luiz de Queiroz" vem pesquisando desde 1971 novas metodologias de pré-limpeza (retirada de pê los) e limpeza (ventilação após a pré-limpeza) dos cariopses da cana-de-açúcar, tendo alcançado aumento superior a $300 \%$ na fertilidade dos lotes. Tendo como meta mecanizar os processos desenvolvidos foram construídos equipamentos especifí cos para esta finalidade. Os equipamentos desenvolvidos estão sendo empregados no Programa de Melhoramento da cana-cle-açūcar do IAA-PLANALSUCAR há vários anos.

o presente trabalho teve como objetivo básico quantificar a eficiência do equipamento e processo referido e os efeitos dos mesmos sobre a qualidade dos cariopses avaliando-se o vigor, germinação e estado nutricional sanitário dos mesmos. 


\section{Revisão de Literatura}

Um dos métodos de melhoramento genético de cana-de-açūcar é efetuado através da obtenção de novos cultí vares por cruzamentos dirigidos e posteriores seleções, com testes de resistência às principais doenças e finalizando com testes de produção em competição com variedades padrões.

A produção dos cariopses dos cruzamentos efetuados e a. obtenção de plântulas para as fases posteriores do processo são os passos iniciais dos programas de melhoramento genético da cana-de-açúcar, e envolvem além dos proble mas relativos à produção de cariopses, um número bastante grande de plântulas a ser manuseado.

No Brasil os dois maiores programas de melhoramento genético são do IAA-PLANALSUCAR e COPERSUCAR, que produzem anualmente mais de 2 milhões de plântulas por insti 
tuição, segundo seus relatórios anuais e tais nümeros indicam elevados custos na condução dos programas.

A inflorescência da cana-de-açúcar é uma paní cula aberta de tamanhos e formatos diversos, e o eixo princi pal ou rāquis dá origem a vārias ramificações secundárias e terciārias, conforme ARTSCHWAGER et alii (1929).

Segundo STEVENSON (1965) as espiguetas ocorrem aos pares, sendo uma pedicelada e outra séssil, e quando maduras, a espigueta pedicelada desarticula-se de seu pedice 1o, o qual, juntamente com o segmento de sustenção do eixo lateral, permanecem ligados à espigueta séssil. Os dois tipos de espiguetas são bastante adaptados à disseminação pelo vento, pois estão equipadas com longos e sedosos pelos, formando um anel em sua base. Cada espigueta tem uma única flor, hermafrodita, constituida por 3 ou 4 glumas conforme a espécie, duas lodículas responsáveis por sua abertura, três estames e ưm único ovário súpero, de forma oval com um só óvulo. O estilete é duplo e os estigmas são alongados e plü mulosos.

ARTSCHWAGER et alii (1929) cita que o fruto da cana-de-açúcar é um cariopse, pequeno, ovalado ou oblongo e varia muito em tamanho, apesar de sua pequenez.

A existência dos longos e sedosos pelos, a 
existência de cariopses sésseis e pedunculados e as variações de tamanho e peso, são os principais pontos que interfe rem diretamente com a pré-limpeza e a limpeza dos cariopses.

Alguns trabalhos citados por SILVA (1974) mos tram várias tentativas de retirada dos pêlos do cariopse, por flambagem ou uso de ảcido sulfūrico, porém todos causaram enormes perdas de germinação. SILVA (1974), em seu trabalho, desenvolveu um processo de produção de "seedlings" de cana-de-açücar pelo beneficiamento do "Fuzz" e transplante precoce, onde desenvolveu dois métodos, um manual e outro mecânico em protótipo de máquinas de beneficiamento de "fuzz", conseguiu assim uma redução de $17 \%$ em pêso e $64 \%$ em volume, apenas com a retirada dos. pêlos, e sem que afetassem a germinação e o vigor, além de facilitar o semeio, transpor te e armazenamento, entre outros.

Posteriormente, SILVA (1977) desenvolveu uma măquina, acrescida de outro motor acionando um aspirador para a retirada do material processado.

Outros autores apresentaram outros processos, cOMO LYRENE (1976) que atritando cariopses em pedaços de câmara de ar de bicicletas rapidamente conseguiu obter grande quantidade de cariopses, porëm completamente descascadas; ob servou também que a retirada total da pálea e lema podem afe tar a germinação, alēm de favorecer a entrada de patögenos. 
DUARTE (1976) e BLEICHER (1978) atritando cariopses entre duas telas finas de nylon também conseguiram a retirada completa da pálea e lema, quando procuravam efetuar testes de inoculação precoce de carvão da cana-de-açūcar. BLEICHER (1978) também concluiu em seu trabalho que o descas camento completo dos cariopses de cana-de-açücar aumenta a mortalidade das plântulas apōs a germinação, e comenta que isto provavelmente se deva ao fato de os embriöes ficarem fe ridos, durante o descascamento sob pressão.

PEERUN et alii (1978) adaptando um escarificạ dor de sementes pela substituição das hastes de metal por ou tra de borracha, que atritavam os cariopses contra escova de pelos curtos, conseguiu rapidamente um grande número de cariopses sem pälea e lema, que era seu objetivo. Considerou tambēm que apenas deverão utilizar o método quando se tratar de cruzamentos pouco valiosos pois temiam a influência do descascamento completo na germinação e armazenamento.

os autores que tem trabalhado com pré-limpeza de cariopses de cana-de-açūcar mostram sempre seu interesse e a importância dessa operação para a produção de plântulas e, até o momento, pela bibliografia consultada, a única tēcnica bem sucedida e empregada foi a de friccionar-se manualmente os cariopses em tapetes de nylon com cerdas de $2 \mathrm{~mm}$ de comprimento; desenvolvida por SILVA (1974). 
BLEICHER (1978) avaliando o efeito da ventila ção na germinação de cariopses de cana-de-açũcar em estudos para a inoculação de Ustilado scitaminea, determinou para um cultivar a existência de $85,3 \%$ de impurezas no lote estudado; determinou tambēm que a utilização de ventilação forçada melhora muito a germinação e vigor do lote, e pode no caso, elevar a germinação em mais de $300 \%$ devido ao aumento da pureza fisica dos cariopses.

Muitos são os fatores que interferem na quali dade das sementes, porém, a presença de microrganismos, sobressai como muito importante. São muitas as espécies de microrganismos que podem ser transmitidos pelas sementes, po dendo causar doenças na própria semente, nas plântulas, nas plântas adultas e mesmo nas plântulas da geração seguinte, conforme comentam TOLEDO e MARCOS FILHO (1977), POPINIGIS (1977) e JUSTICE e BASS (1978).

O primeiro relato de Helminthosporium sacchari em cariopses de cana-de-açúcar è de Lovelles e Smith (1956) citados por SANGUINO (1976).

BYTHER e STEINER (1972) citam como patógenos de plântulas de cana-de-açúcar os fungos H. rostratum, H. ha vaiensis, Curvularia lunata e $C$. senegalensis, no Havai.

SANGUINO (1976) em estudos com cariopses de 
cana-de-açūcar encontrou uma série de fungos patógenos que podem causar a morte de plântulas logo após a germinação ou após o transplante. O mesmo autor, em levantamento executado em cariopses de 45 progênies determinou que os gêneros Helinthosporium sp., Curvularia sp, Phoma sp. e Fusarium sp. foram os mais frequentes. O mesmo autor mostrou ser maior a incidência desses patógenos nas cascas separadas dos cariopses. Resultados semelhantes quanto aos microrganismos mais frequentes foram relatados por SILVA (1978) e DIAS (1981).

DUARTE (1976) e DUARTE e. TOKESHI (1978) verificaram a colonização dos tecidos de plântulas de cana-de-açūcar por Helminthosporium sp., Phoma sp e Curvularia sp. sendo esses fungos também observados por BLEICHER (1978) ao examinar plântulas mortas.

TOKESHI (1980), em estudos sobre a patologia de sementes de cana-de-açúcar, mostra que a maioria dos microrganismos patogênicos da parte aérea da cana-de-açúcar po de parasitar seus cariopses, e que as condições climáticas das estações de cruzamento favorecem o ataque de outros microrganismos comuns a outras gramíneas. Comenta também que a baixa fertilidade e baixo vigor dos cariopses da cana-cle-açūcar, são também consequência da presença dos microrganis mos patogênicos. 
DIAS (1981) ao interpretar três ensaios com diferentes cultivares inoculados e não inoculados com 11 . sci taminea, associados com diferentes fotoperiodos e substratos de germinação, concluiu que a mortalidade de plântulas de cana-de-açúcar, após o transplante, tem como causa principal a presença de microrganismos patogênicos nos cariopses.

CAZALET e BERJAK (1983), na Africa do Sul, ve rificaram a colonização dos tecidos embrionārios de cariopses de cana-de-açúcar por Penicillium spp e nada comentaram sobre outros gêneros e espécies.

o término do processo de beneficiamento com a separação total das impurezas, sementes doentes e a classifí cação em tipos conforme definem TOLEDO e MARCOS FILHO (1977) em cariopses de cana-de-açúcar é muito difícil como pôde-se observar. Sua necessidade fica evidente quando se percebem as melhorias advindas com redução de peso, volume, melhorias de germinação, vigor e sanidade dos lotes de cariopses.

O autor deste trabalho, nas atividades rotineiras de processamento, sempre encontrou em lotes já ventilados, pedúnculos florais ou partes deles, presos ou não aos cariopses de diversos tamanhos e pesos, cascas com grãos abortados, com restos de órgãos florais ou vazias. Esses elementos compõem um material muito heterogêneo e dificil de 
.10 .

ser separado pela ventilação, devido às similaridades de den sidade e resistência aerodinâmica à força do vento. 
.11 .

\section{Material e Métodos}

O presente trabalho foi desenvolvido no Depar tamento de Fitopatologia da ESALQ/USP e na Estação Experimen tal Central da Coordenadoria Regional Nordeste (COONE) do IAA-PLANALSUCAR .

3.1. Descriçáo da mäuina de prë-limpeza dos cariopses de cana-de-ą̧ücar

A máquina de pré-limpeza dos cariopses de cana-de-açūicar está montada sobre uma base de ferro de $10 \mathrm{~mm}$ de espessura, com $600 \mathrm{~mm}$ de frente e $400 \mathrm{~mm}$ de lado, possuin do nos cantos e parafusados à base, 4 pês de borracha para fixação no local de trabalho e seus desenhos são apresentados nas Figuras 1 a 7. 


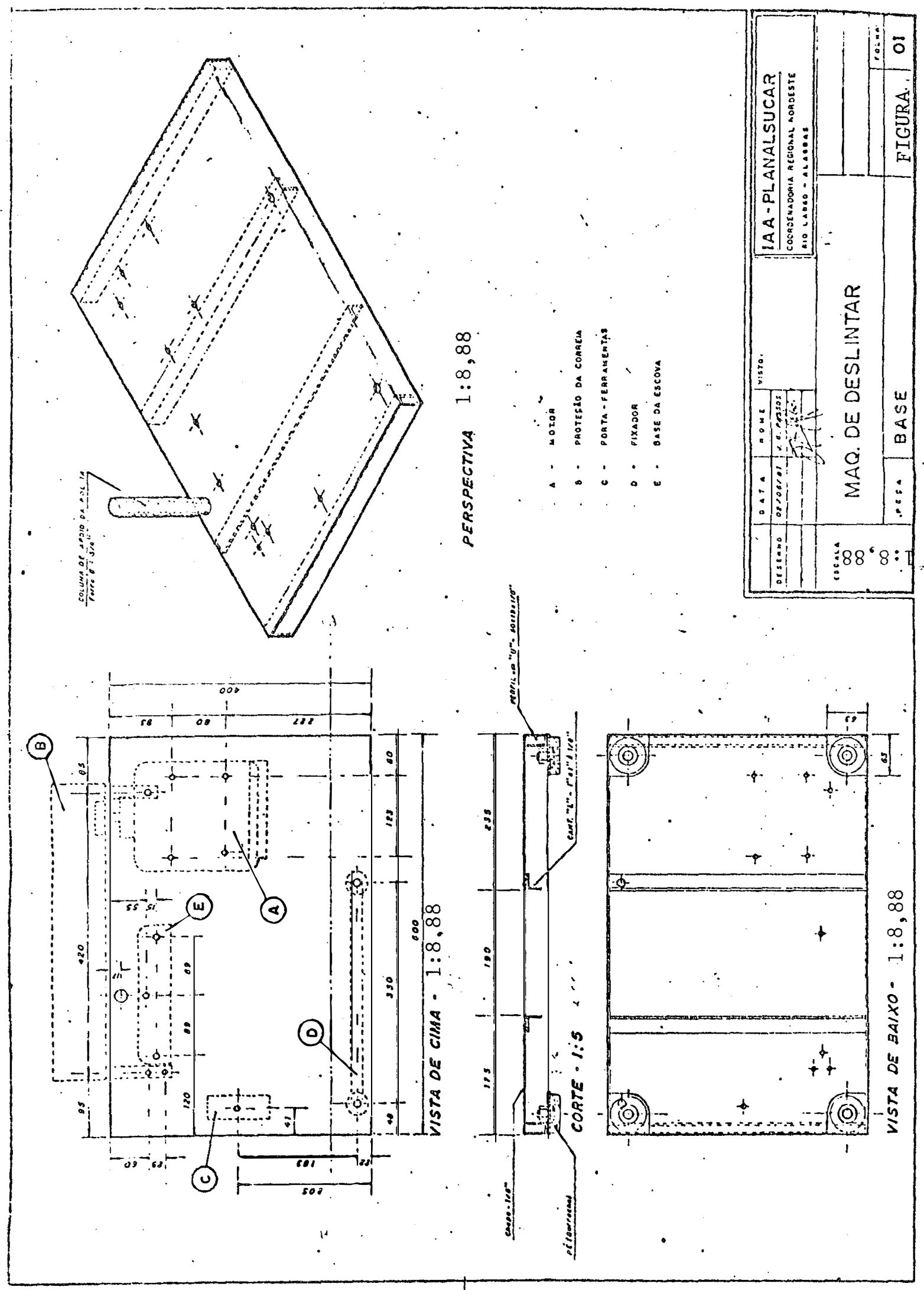




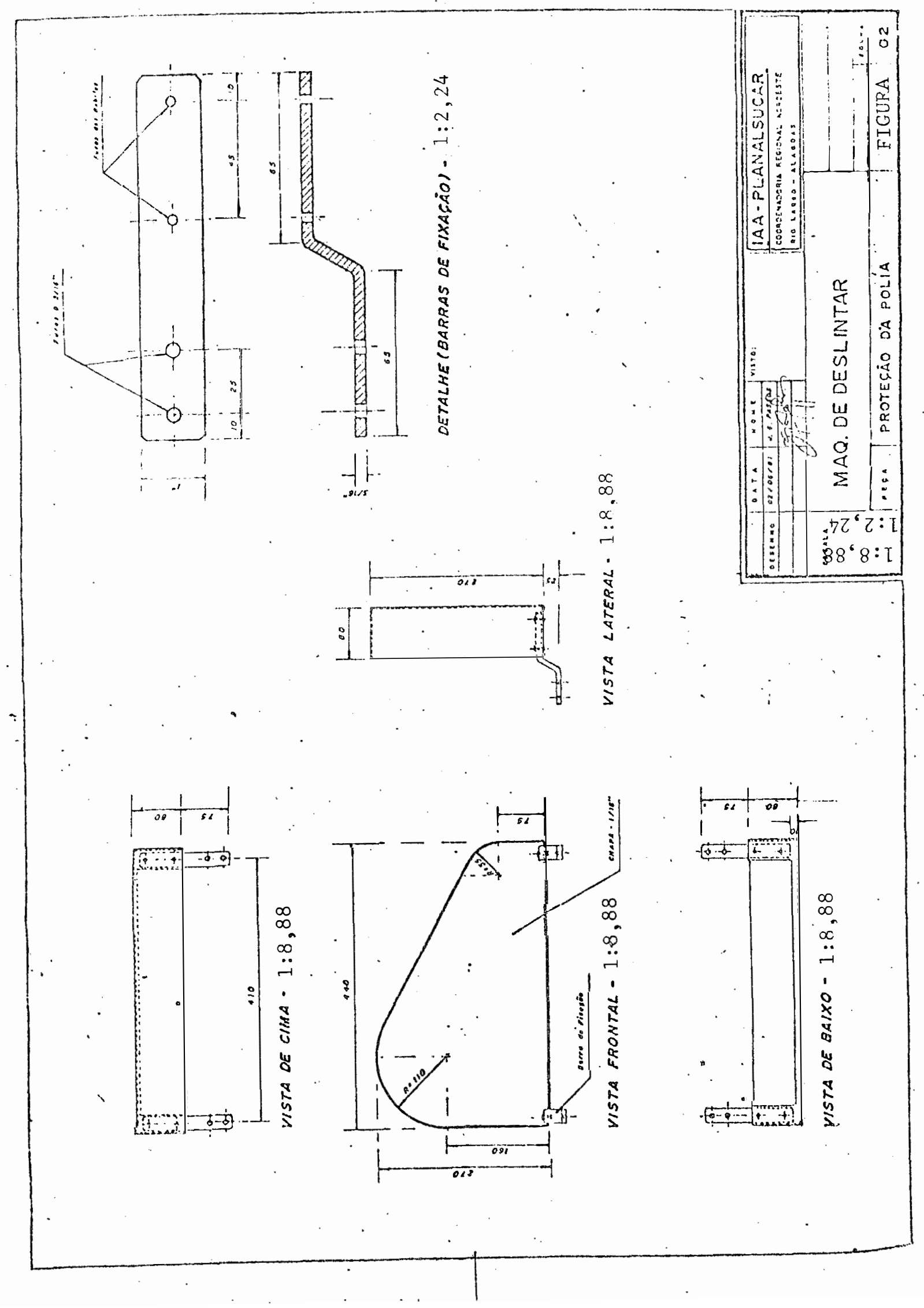


.14.

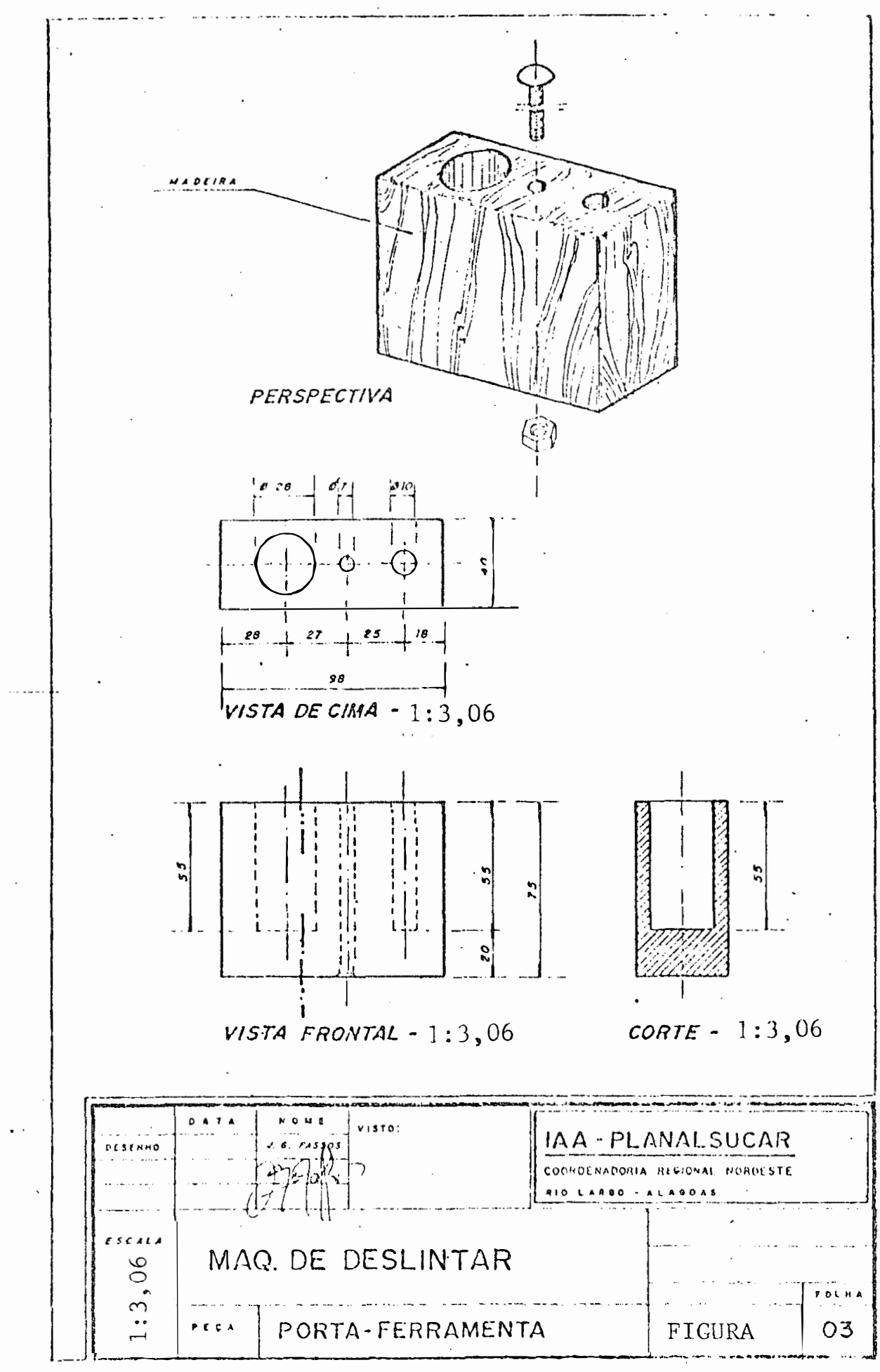




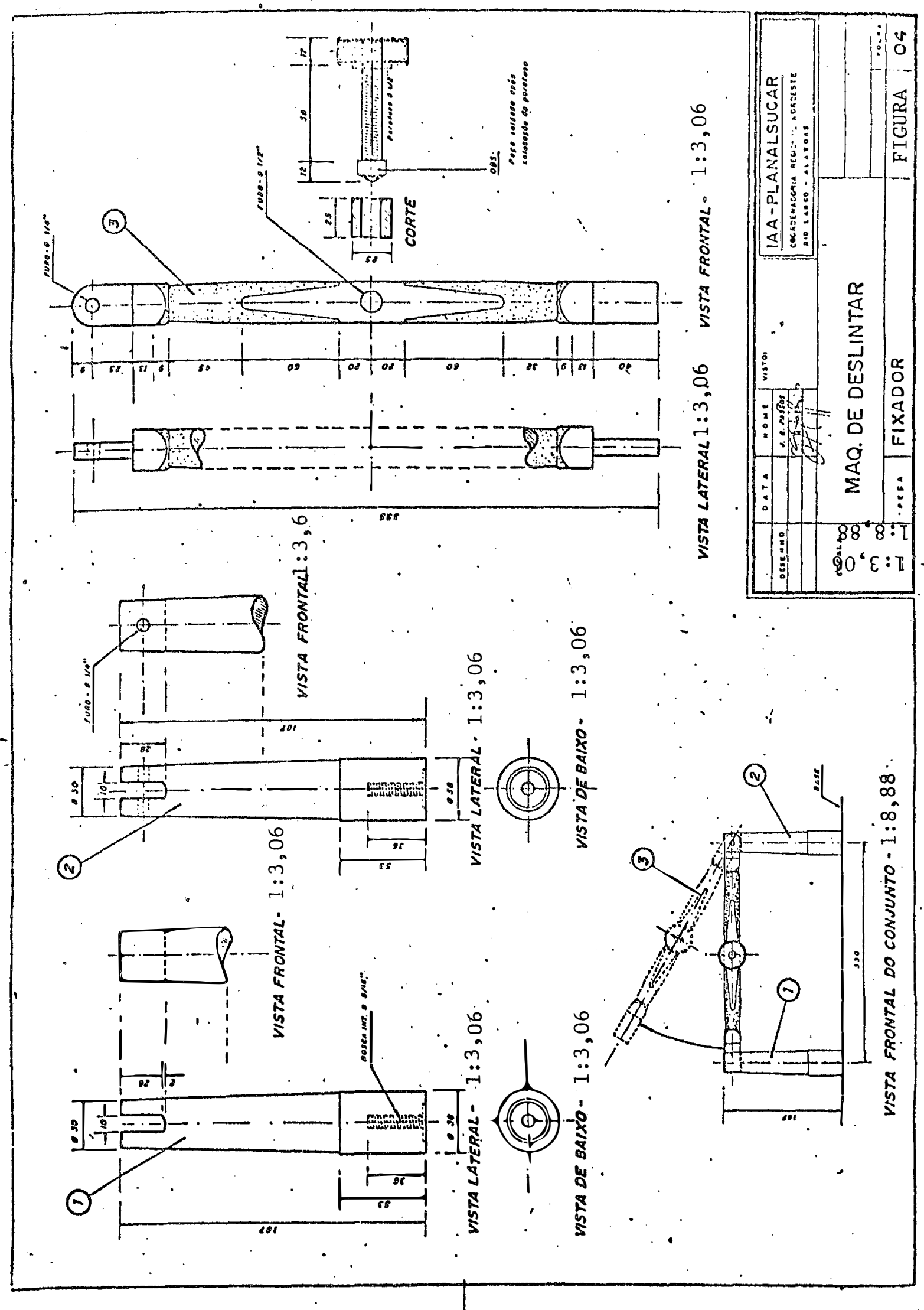




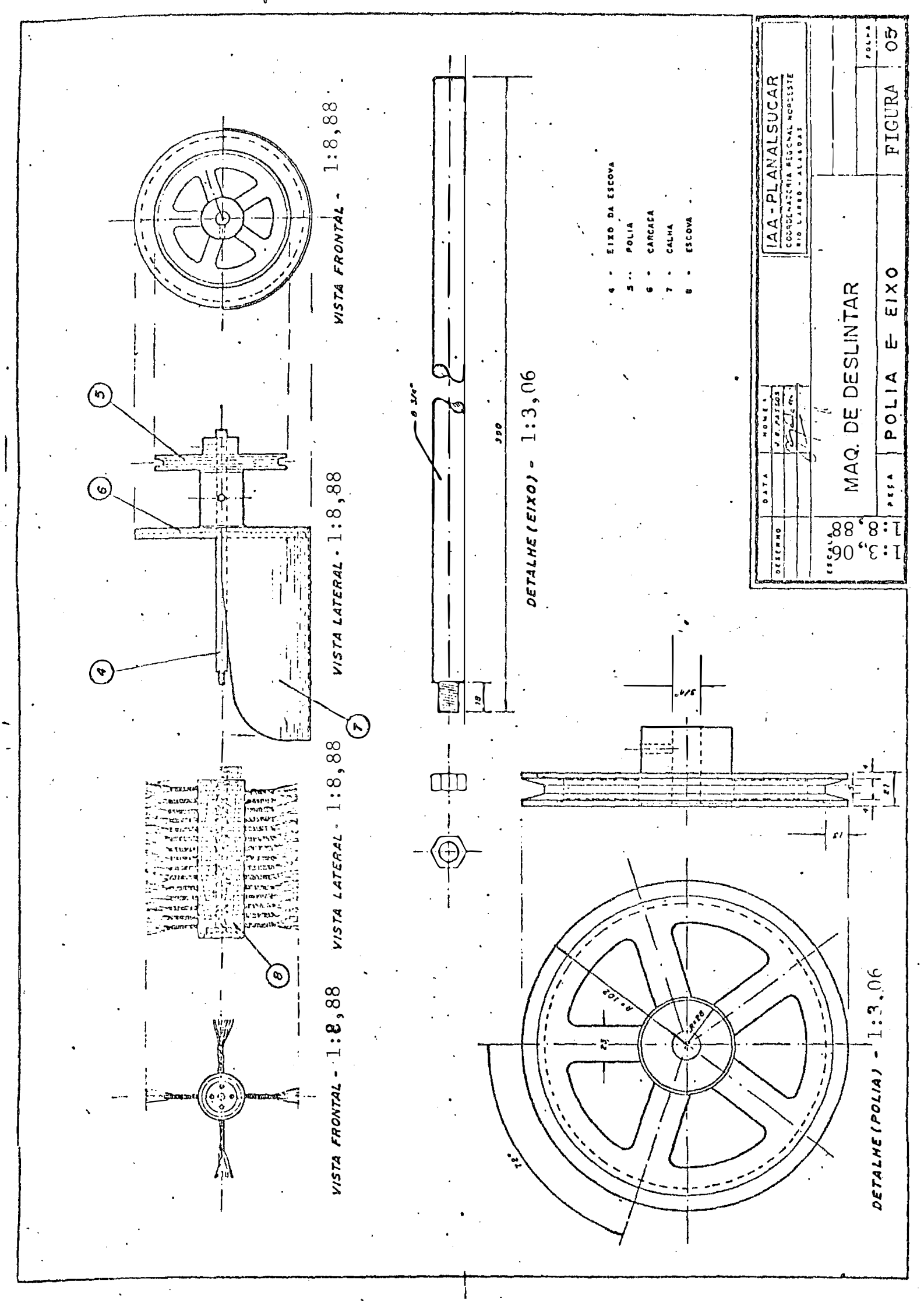




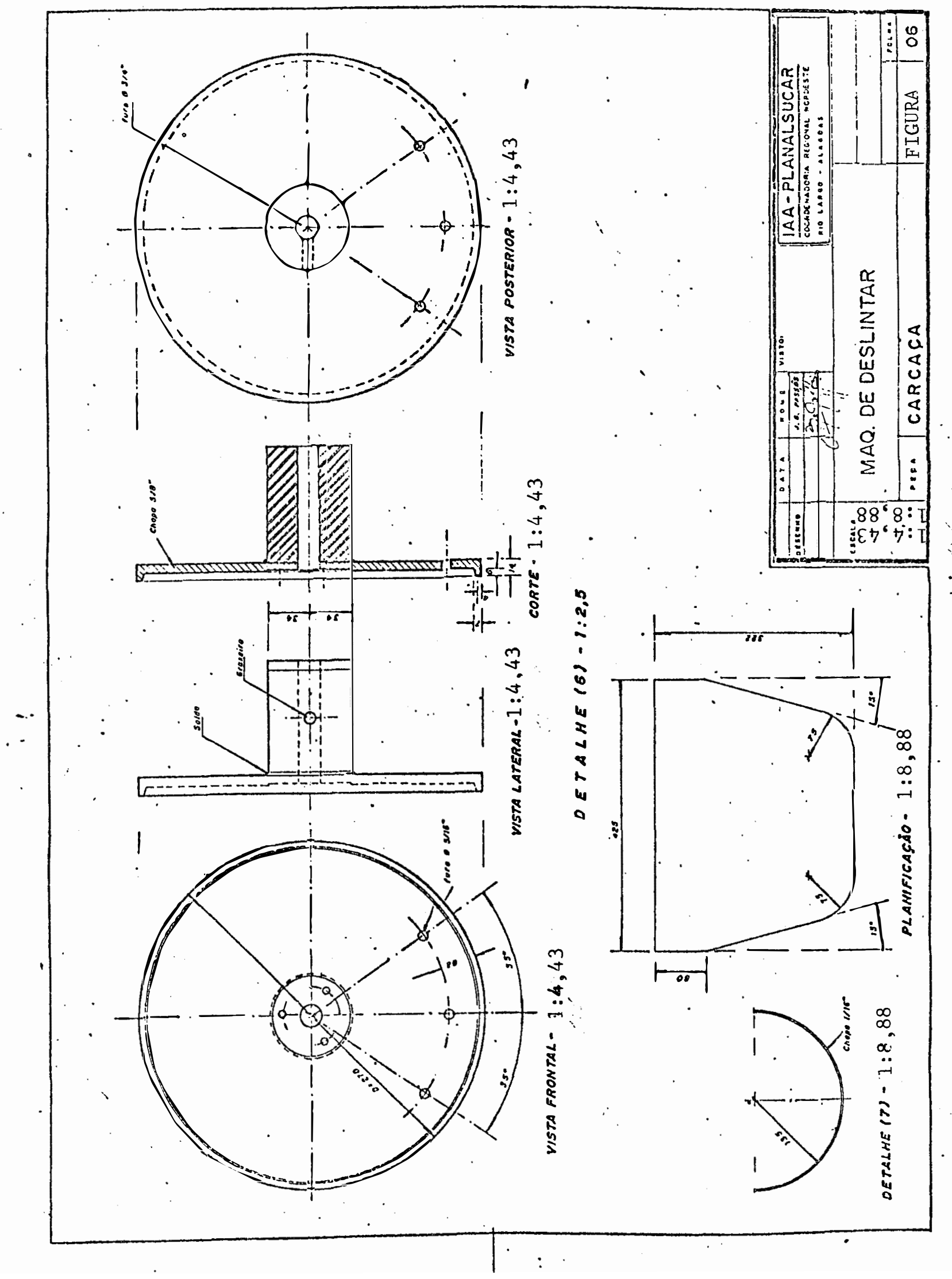




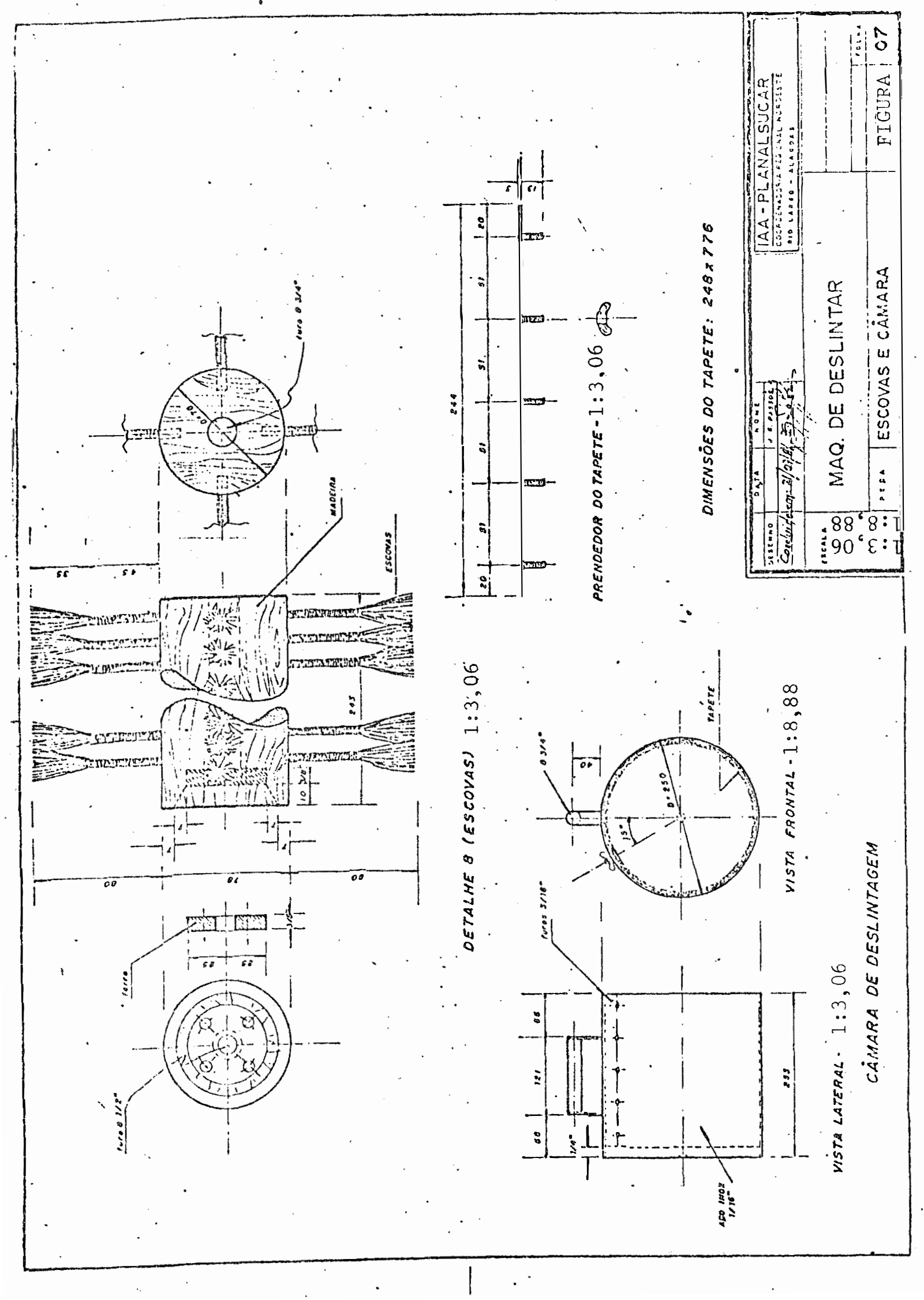


A mäquina ê formada por 5 componentes principais, todos fixados à base por parafusos e a seguir descritos.

\subsubsection{Motor}

A fonte de potência da máquina ë um motor elé trico assincrono monofásico com $1 / 3$ de $C . V$. de potência num regime de $1.500 \mathrm{rpm}$ tendo acoplado ao seu eixo uma polia de 76,2 mm de diâmetro, para utilização de correia em "V". acionamento é feito por chave elétrica de segurança.

\subsubsection{Base da escova}

Trata-se de uma carcaça de sustentação do man cal e eixo horizontal, de $18 \mathrm{~mm}$ de diâmetro. Na fase anterior está a escôva de fricção montada no eixo e na parte pos terior está uma polia de $204 \mathrm{~mm}$ de diâmetro, que recebe a correia ligado ao motor. A carcaça é constituída de uma chapa de ferro de $10 \mathrm{~mm}$ de espessura, soldada ao mancal na face posterior. Na face anterior há um bordo externo circular de $4 \mathrm{~mm}$ circundando uma reentrância de $6 \mathrm{~mm}$ de profundidade e $256 \mathrm{~mm}$ de diâmetro centrada no eixo do conjunto, onde se acoplará a câmara de pré-limpeza quando em operação. 
Revestindo o eixo na parte frontal da carcaça está a escova de fricção, que é constituída por um cilindro de madeira de $243 \mathrm{~mm}$ de altura e diâmetro $78 \mathrm{~mm}$, fixados ao eixo na parte frontal por quatro parafusos. Conforme dois eixos ortøonais há 4 séries de 15 furos de $10 \mathrm{~mm}$ no cilindro de madeira onde se encaixam os tufos de fios plásticos que formam a escôva; da base dos tufos até $45 \mathrm{~mm}$ de altura os tufos de fios plásticos são encordoados para maior resistência. A velocidade da escova no tapete é cêrca de $8 \mathrm{~m} / \mathrm{s}$ e sua rotação è de $662 \mathrm{rpm}$.

Proteção da correia: é um item de segurança para proteção da correia em "V" que transmite através das po lias a potência do motor à escôva. É fixada à base por para fusos e construída em chapa de ferro de $2 \mathrm{~mm}$ recobrindo com folga a silhueta das polias, sendo a maior altura de $270 \mathrm{~mm}$ e possui uma aba lateral de $80 \mathrm{~mm}$.

\subsubsection{Càmara de pré-1 impeza}

¿ um cilindro ôco, fechado numa das bases, com uma alça para manuseio e transporte; é construỉdo em chapa inoxidável de $2 \mathrm{~mm}$ de espessura e o diâmetro externo é de $250 \mathrm{~mm}$ com uma altura de $253 \mathrm{~mm}$. Possui na parede lateral 5 oxificios de $5 \mathrm{~mm}$ de diâmetro que permitem a colocação e fi- 
xação do prendedor do tapete de nylon.

o prendedor do tapete é um retângulo da mesma chapa inoxidävel, com $253 \mathrm{~mm}$ de comprimento e $30 \mathrm{~mm}$ de largu ra, tendo na sua linha média no sentido do maior comprimento de una das faces 5 pitões com rosca soldados à superficie, distando os dois mais extremos $20 \mathrm{~mm}$ das extremidades e entre si. $51 \mathrm{~mm}$; colocando-se a peça descrita no interior do cilinaro, de maneira que cada pitão com rosca encontre o or fícic correspondente, pode-se por meio de borboletas rosquea das externamente fixar a superfície de fricção.

A superfície de fricção utilizada é semelhante a utilizada por SILVA (1974). Para sua perfeita adequação ao interior do cilindro, é um retângulo de 762 x $253 \mathrm{~mm}$, que quando introduzido com a superfície de cerdas para fora e suas extremidades fixadas pelo prendedor, forma então a câa mara de pré-limpeza.

\subsubsection{Fixador da càmara}

E um conjunto com a função de prender firmemente a câmaxa de pré-limpeza à carcaça da escova de fricção.

E formado por duas hastes de ferro de $38 \mathrm{~mm}$ 
de diāmetro, firmemente fixadas por parafusos à base, distan do entre si $330 \mathrm{~mm}$. Tem $187 \mathrm{~mm}$ de altura e no topo possuem uma ranhura de $10 \mathrm{~mm}$ onde se encaixa perfeitamente um braço móvel tambëm de ferro e fixo à haste da direita por um eixo de $6 \mathrm{~mm}$ de diâmetro.

Após a colocação da câmara na base da carcaça, baixa-se o braço móvel, e por meio de um parafuso com $14 \mathrm{~mm}$ de diâmetro ligado a uma empunhadura de $40 \mathrm{~mm}$, perfeitamente centrado ao eixo da carcaça e ao centro da câmara em uma reentrância cônica na sua base, exerce-se a pressão para que o conjunto fique preso e possa ser operado.

\subsubsection{Porta ferramentas}

Trata-se de um paralelepipedo de madeira com dimensões de 98 × 45 x $75 \mathrm{~mm}$, fixado à base por um parafuso e com dois orifícios de $28 \mathrm{~mm}$ e outro com $10 \mathrm{~mm}$ de diâmetro, no sentido vertical, para guarda de chave de boca e chave de fenda.

3.2. Escolha da superfície de fricção complementar

A composição heterogênea do material apös prë- limpeza e limpeza, indicava a necessidade de um aprimoramen 
to no processo, de tal forma que provocasse a melhor separação dos pedünculos. Adimitiu-se então a possibilidade da utilização de uma superfície de friç̧ão que preparase melhor o material a ser ventilado.

Neste ensaio pxeliminar utilizou-se cariopses de cultivar co 678 obtidos por cruzamento multiplo e com o progenitor masculino desconhecido.

o material estava armazenado a 3 meses em des secadores com silica-gel a $15^{\circ} \mathrm{C}$ (armazenamento padrão) e já havia sido limpo mecanicamente conforme a rotina de trabaIho na Coordenadoria Nordeste.

Após o ensaio preliminar com sete diferentes tipos de superfície, observou-se que o plástico lonado "original kombi", fabricado pela indústria IDMA, o qual possui pequenas ranhuras de $1 \mathrm{~mm}$ de largura e 0,5 mm de profundidade, distando as ranhuras entre si $10 \mathrm{~mm}$, foi o mais indicado, pelo menor dano provocado nos cariopses, e denominado Superfície de Friç̧ăo Complementar (SFC).

Utilizou-se também, para melhor observar o ma terial assim trabalhado, a ventilação forçada por dois minutos, em aparelho semelhante ao descrito por BLEICHER (1978), sendo este porēm um similar nacional, fabricado por EQUILABOR, de Piracicaba, São Paulo. O modelo similar, possui 
pressão māxima menor, sendo então sua regulagem bem mais sua ve. A abertura utilizada para a ventilação foi constante pa ra cada tratamento e determinada por sucessivas amostragens das impurezas eliminadas e aumentos de abertura, até 0,1 de grau a menos do limite que permite a passagem de algum cariopse.

Outro ensaio preliminar foi executado, estudando-se três tempos de operação da máquina de pré-limpeza e variando-se também o teor de umidade dos cariopses, utilizando-se porções recém tiradas do armazenamento padrão e outra com $20 \mathrm{~h}$ em recipiente aberto nas condições ambientais naturais.

As porções iguais de cariopses foram inicialmente ventiladas até seu limite, para serem mecanicamente submetidos à fricção com o plástico lonado anteriormente des crito, nos tempos de 10,20 e 30 segundos. Observou-se o nú mero de cariopses completamente descascados; foram feitas também pesagens de 10 amostras de 1.000 sementes ventiladas acima de seu limite de abertura do soprador e obteve-se valo res que possibilitaram o cálculo aproximado da o de sementes descascadas no volume final das amostras (cerca de 8.000 cariopses em $3 \mathrm{~g}$ ). 
3.3. Eficiēncia dos tratamentos de pré-limpeza dos cariop ses determinadas após ventilação e avaliadas pelas diminuiçoes de volume e peso, pela porcentagem de germinaçào e indice de vigor

Neste experimento utilizou-se uma mistura de cariopses provenientes de polinização livre, ainda com os pelos, e formado por várias panículas dos cultivares CB45-3 CP57-614, CP66-346, F 151, H39-3633, MEX 60-1459, Q 73 e RB72454, para assegurar-nos da disponibilidade de material para os testes e para obtermos dados médios de eficiência. Após exaustiva homogenização o material foi separado em seis porções semelhantes e a seguir foram efetuados os tratamentos de pré-limpeza.

Usou-se como tratamento padrão (manual) a téc nica de pré-limpeza manual em carpetes de nylon com cerdas de $2 \mathrm{~mm}$, conforme técnica desenvolvida por SILVA (1974).

Utilizou-se mais três tratamentos para pré- limpeza, todos mecânicos com a máquina descrita, tendo-se variado os tempos de operação que foram 40,60 e 80 segundos $(40 \mathrm{~s}, 60 \mathrm{~s}$ e $80 \mathrm{~s})$.

outros dois tratamentos de pré-limpeza foram executados mecanicamente com o plástico lonado anteriormente descrito, que foi escolhido como superfície de fricção com- 
plementar (SFC) para os quais trabalhou-se com cariopses anteriormente processados pelo tratamento $60 \mathrm{~s}$; utilizou-se os tempos de operação de 10 e 20 segundos $(60 \mathrm{~s}+10 \mathrm{C}$ e $60 \mathrm{~s}+$ 20 c), previamente escolhidos como menores causadores de des cascamentos conforme visto em 3.2 .

As porçöes assim preparadas foram então divididas em 6 parcelas cada, uniformizando-se o peso em $4,5 \mathrm{~g}$ e anotando-se os volumes correspondentes, utilizando-se balangas com procisão de 0,19 e provetas de $25 \mathrm{ml}$.

A técnica utilizada não determinou as reduções de volume e pêso obtidos com a retirada dos pelos dos cariopses, considerando bastante suficiente os valôres de $64 \%$ e $17 \%$ em volume e peso, respectivamente, determinados por SIIJVA (1974).

A preocupação maior foi com a influência dos tratamentos na fase seguinte, ou seja na maneira como preparavam o material para a limpeza a ser efetuada pela ventila̧̧ăo.

A operaço de limpeza dos cariopses fol complotada utilizando-se o sopradox de sementes anteriormente referido, sendo constante para cada tratamento a abertura de sajaa do aparelho o que permitiu escolher os melhores limites de cada um deles, tambëm pela tëcnica descrita anteriormente. 
Todo material descartado pela ventilação foi colocado em condições normais para a germinação, para assegu rar-nos da correta abertura de saida do soprador.

3.3.1. Eficiencia dos tratamentos de prë-limpeza dos cariopses determinadas apös a ventilaçäo e avaliadas pela reduçăo de volume

Determinou-se a seguir o volume de cada parce la obtendo-se assim o volume final utilizado para cálculo de sua redução devido aos tratamentos, também com provetas de $25 \mathrm{ml}$ com divisões de $1 \mathrm{ml}$.

3.3.2. Eficiência dos tratamentos de pré-limpeza dos cariopses determinadas após a ventilação e avaliadas pela redução de peso

Determinou-se o peso de cada parcela obtendo-se assim o peso final utilizado para os cálculos de sua redução devido aos tratamentos, também com balança de 0,1 g de precisão. 
3.3.3. Eficiēncia dos tratamentos de pré-limpeza dos cariopses determinadas apös a ventilação e avaliadas pela porcentagem de germinaçăo.

Os testes de germinação descritos por MARCOS F'o et ali (1983) necessitam de algumas repetições perfazendo un total de 400 sementes puras; nos trabalhos de SILVA (1974) o autor utilizou 100 cariopses por repetiçăo tocadas uma a uma com estilete, para assegurar-se de sua pureza fís ca e para maiox confiabilidade do experimento.

No nosso caso, como dispunhamos de grande quantidade de cariopses e não dispunhamos de germinador, para nos assegurarmos da pureza física e maior segurança, opta mos por trabalhar com um nümero bem mais elevados de cariopses, após ter novamente ventilado parte de cada amostra com abertura 5 décimos de ponto acima do limite utilizado para a separação normal.

Assim, cada repetição constou de 1.000 cariop ses.

o material foi colocado para germinar em local coberto com telhas translúcidas tendo períodos de luz al ternados; para suprix a umidade foram feitas as regas que se fizeram necessärias e ao entardecer colocava-se sobre as cai xas uma abertura plástica transparente, que era retirada no 
inĩcio da manhã seguinte. Essa operaçăo foi utilizada para manter o mais constante possivel a temperatura, que pouco os cilava na época de outubro/novembro na sede da Estação Experimental, prōxima a Maceió, Al.

o substrato de germinação utilizado era composto de uma parte de torta de filtro oliver curtida e duas de terriço de mata, com residuos de desempenadeira no fundo das caixas; foi humigado com brometo de metila e arejado, conforme procedimento padrão utilizado na produçãa de plântú las do programa de melhoramento da coordenadoria.

3.3.4. Eficiencia dos tratamentos de pré-i impeza dos cariopses determinadas apôs a ventilação e avaliadas pelo indice de vigor

As avaliações do vigor dos cariopses foram feitas conforme propõe BYRD (1957) e confirmado por MARCOS Filllo et alii (1983), baseando-se o mëtodo na velocidade de emergência das plântulas, tendo sido iniciadas as contagens no quarto dia após a semeadura e encerradas no décimo primei ro dia. 
3.4. Determinaçăo do rendimento da mäquina de prē-limpeza

Na preparação dos tratamentos de pré-limpeza para as determinações a serem feitas a seguir, anotou-se tạ bẻm os tempos de operação para cada tratamento.

Os tempos de operação da măquina foram fixos em decorrência dos tratamentos e para o volume processado correspondente a $10 \mathrm{~g}$ de cariopses com pelos, foi necessário dividir o volume para 2 operações por tratamento mecânico, e 5 para o manual, somando-se os tempos obtidos.

3.5. Sanidade de cariopses sem cascas e cascas apös prë- Timpeza e limpeza, e de cariopses com pêlo

Do material processado pelos tratamentos reti rou-se amostras para as observações, e os cariopses com pêlos vieram da mistura original.

Na separação das cascas e sementes descascadas e desinfecção procedeu-se como SANGUINo (1976). O regime de luz foi alternado, com temperaturas variando de $28 \pm$ $3^{\mathrm{O}} \mathrm{C}$.

Cada tratamento foi composto de 8 placas de Petri com 25 unidades cada. 
No 6: dia apös o plaqueamento foram retiradas e anotadas as unidades sem infecção, iniciando-se a identifi caçào e contagem dos fungos, com a última indentificação rea lizada no 110 dia.

Os fungos presentes foram identificados conforme BARNETT e HUNTER (1972). 
.32 .

\section{RESUltados}

4.1. Escolha da superficie de friccão complementar

Após as determinações conforme descritas em 3.1. observoumse que os tempos de $10 \mathrm{~s}$ e $20 \mathrm{~s}$ foram os que menos descascamentos causaram.

Os resultados obtidos estão demonstrados na Tabela 1. 
TABELA 1. Número e percentagem de cariopses descascados pela superficie de frição complementar, trabalhando com dois teores de umidade em volume correspondente a 8000 cariopses.

\begin{tabular}{|c|c|c|c|c|c|c|}
\hline \multirow[t]{2}{*}{ Tratamentos al } & \multicolumn{3}{|c|}{$\begin{array}{c}\text { Número de cariopses } \\
\text { descascados }\end{array}$} & \multicolumn{3}{|c|}{$\begin{array}{r}\text { Porcentagem } \\
\text { Descascamento }\end{array}$} \\
\hline & $10 \mathrm{~s}$ & $20 \mathrm{~s}$ & $30 \mathrm{~s}$ & $10 \mathrm{~s}$ & $2.0 \mathrm{~s}$ & $30 \mathrm{~s}$ \\
\hline $\begin{array}{l}\text { Armazenamento em } \\
\text { silica gel }\end{array}$ & 46 & 56 & 221 & 0,57 & 0,70 & 2,76 \\
\hline $\begin{array}{l}\text { Armazenamento em } \\
20 \text { horas em con } \\
\text { dições ambientāis }\end{array}$ & 12 & 14 & 86 & 0,15 & 0,17 & 1,07 \\
\hline
\end{tabular}

4.2. Eficiência dos tratamentos de pré-limpeza dos cariopses determinadas após a ventilacăo e avaliadas pela reducăo de volume.

A análise de variância revelou valor de $\mathrm{F}$ sig̣ nificativo ao nivel de 1\% de probabilidade para os vários tratamentos de pré--limpeza e ventilação utilizados.

Os resultados das repetições e médias de redü ção de volume em porcentagem estão demonstrados na Tabela 2. 
TABELA 2. Redução de volumes obtidos nela pré-limpeza e limpeza. Valores em porcentagem.

\begin{tabular}{|c|c|c|c|c|c|c|c|}
\hline \multirow{2}{*}{ Tratamentos } & \multicolumn{6}{|c|}{ Repetições } & \multirow{2}{*}{ Médias } \\
\hline & 1 & 2 & 3 & 4 & 5 & 6 & \\
\hline Manual & 68 & 67 & 71 & 70 & 66 & 68 & $68,33 \mathrm{ab}$ \\
\hline $40 \mathrm{~s}$ & 50 & 49 & 51 & 47 & 47 & 45 & $48,17 d$ \\
\hline $60 \mathrm{~s}$ & 63 & 58 & 61 & 58 & 61 & 63 & $60,67 c$ \\
\hline $80 \mathrm{~s}$ & 65 & 68 & 62 & 64 & 61 & 63 & $63,83 \mathrm{bc}$ \\
\hline $60 s+10 c$ & 68 & 64 & 66 & 66 & 69 & 63 & $66,00 \mathrm{bc}$ \\
\hline $60 s+20 c$ & 70 & 69 & 74 & 71 & 75 & 74 & $72,17 a$ \\
\hline$C . V .=3,60$ & DMS & $5 \frac{\circ}{\partial}=$ & 39 & & DMS 1\% & $=4,87$ & \\
\hline
\end{tabular}

Obs.: Médias com letras iguais nảo diferem estatisticamente ao nivel de $1 \%$ de probabilidade.

4.3. Eficiencia dos tratamentos de pré-limpeza dos cariop ses determinadas após ventilação e avaliadas pela re duçäo de peso

A análise de variância revelou valor de $F$ sig nificativo ao nível de $1 \%$ de probabilidade para os vários tra tamentos de pré-limpeza e ventilação utilizados.

Os resultados das repetições e médias da redu 
cão de peso em porcentagem estã demonstrados na Tabela 3.

TABEIA 3. Re Uuço de pesos obtidos pela pré--limpeza e limpeza. Valores em porcentagem.

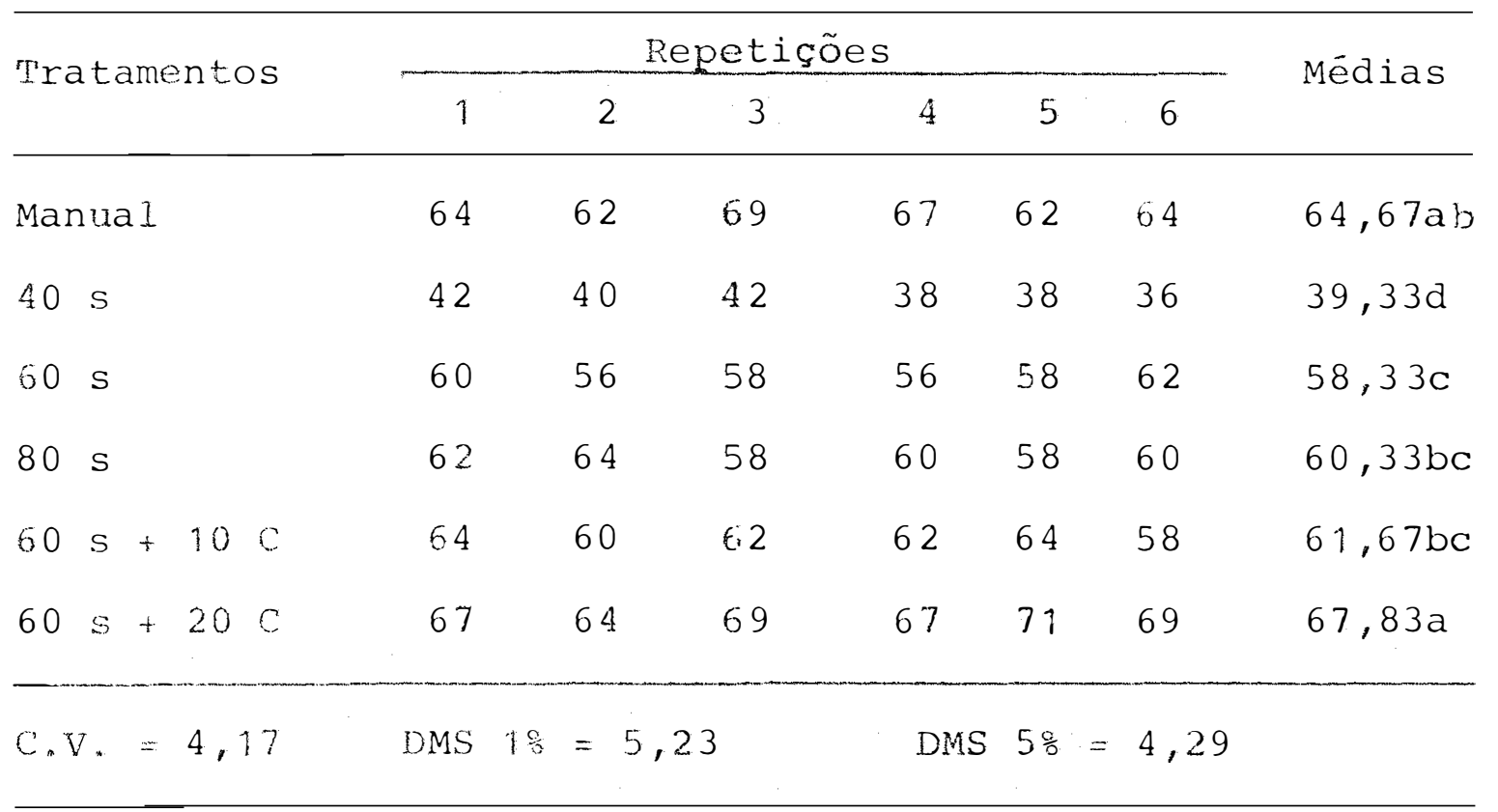

obs.: médias com letras iguais nã diferem estatisticamente ao nivel de 1 \% de probabilidade.

4.4. Eficiência dos tratamentos de prē-limpeza dos cariop ses determinadas apōs ventilacäo e avaliadas pela germinação

A análise de variância revelou valor de $F$ não significativo. 
Os resultados das repetições e médias em porcentagem de germinação são demonstrados na Tabela 4 .

TABELA 4. Porcentagem de germinação dos cariopses submetidos a pré-limpeza.e limpeza.

\begin{tabular}{|c|c|c|c|c|c|c|c|}
\hline \multirow{2}{*}{ Tratamentos } & \multicolumn{6}{|c|}{ Repetições } & \multirow{2}{*}{ Médias } \\
\hline & 1 & 2 & 3 & 4 & 5 & 6 & \\
\hline Manual & 36 & 35 & 37 & 38 & 36 & 36 & $36,53 a$ \\
\hline $40 \mathrm{~s}$ & 34 & 36 & 38 & 39 & 37 & 36 & $36,64 a$ \\
\hline $60 \mathrm{~s}$ & 38 & 40 & 33 & 38 & 35 & 34 & $36,37 a$ \\
\hline $80 \mathrm{~s}$ & 36 & 35 & 37 & 38 & 39 & 34 & $36,44 a$ \\
\hline $60 s+10 c$ & 37 & 35 & 36 & 38 & 37 & 35 & $36,56 a$ \\
\hline $60 s+20 c$ & 37 & 37 & 35 & 37 & 37 & 38 & $36,84 a$ \\
\hline$C \cdot V_{0}=4,60$ & DMS & $1 \%=$ &, 39 & & DMS 5 & $=$ & \\
\hline
\end{tabular}

Obs.: Médias com letras iguais não diferem entre si ao nível de $1 \%$ de probabilidade.

4.5. Eficiéncia dos tratamentos de pré-limpeza dos cariopses determinadas após ventilação e avaliadas pe 10 vigor

A análise de variância revelou valor de $F$ não significativo. 
os resultados das repetições e médias em Vinclice de vigor são apresentados ua Tabela 5.

TABELA 5. Vigor dos cariopses submetidos aos tratamentos de prë-limpeza e limpeza. Resultados em $\sqrt{\text { indice de vigor }}$

\begin{tabular}{|c|c|c|c|c|c|c|c|}
\hline \multirow{2}{*}{ Tratamentos } & \multicolumn{6}{|c|}{ Repeticões } & \multirow{2}{*}{ Médias } \\
\hline & 1 & 2 & 3 & 4 & 5 & 6 & \\
\hline Manual. & 7,76 & 7,62 & 7,90 & 7,90 & 7,81 & 7,83 & 7,810 \\
\hline $40 \mathrm{~s}$ & 7,58 & 7,78 & 8,03 & 8,06 & 7,85 & 7,74 & $7,84 a$ \\
\hline $60 \mathrm{~s}$ & 7,98 & 8,13 & 7,51 & 7,92 & 7,68 & 7,29 & $7,75 a$ \\
\hline $80 \mathrm{~s}$ & 7,76 & 7,65 & 7,64 & 8,02 & 8,08 & 7,56 & $7,79 a$ \\
\hline $60 s+10 c$ & 7,83 & 7,78 & 7,78 & 7,99 & 7,90 & 7,68 & $7,83 a$ \\
\hline $60 \mathrm{~s}+20 \mathrm{c}$ & 7,89 & 7,92 & 7,70 & 7,88 & 7,84 & 7,98 & $7,87 a$ \\
\hline$C \cdot V .=2,40$ & & DMS 1\% & $=0,40$ & & $5 \%=$ &, 33 & \\
\hline
\end{tabular}

Obs.: Médias com letras iguais não diferem estatisticamente entre si ao nivel de $1 \%$ de probabilidade.

4.6. Avaliacăo do rendimento dos processos de pré-limpeza

Os tempos obtidos para pré-limpeza mecânica e manual foram anotados e calculou-se o ganho de tempo em por- 
centagem (eficiência).

os resultados obtidos são demonstrados na Tabela 6.

TABEIA 6. Tempo gasto para a prē-limpeza de 10,0 g de carip ses com pelo, manual e mecanicamente e a eficiência em porcentagem.

\begin{tabular}{lcc}
\hline Tratamentos & $\begin{array}{c}\text { Tempo qasto } \\
\text { em segundos }\end{array}$ & $\begin{array}{c}\text { Ganho de } \\
\text { tempo } \\
\text { (eficiềncia) }\end{array}$ \\
\hline Manual & 882 & 0 \\
$60 \mathrm{~s}$ & 120 & 86,4 \\
$80 \mathrm{~s}$ & 160 & 81,8 \\
$60 \mathrm{~s}+10 \mathrm{C}$ & 140 & 84,1 \\
$60 \mathrm{~s}+20 \mathrm{C}$ & 160 & 81,8 \\
\hline
\end{tabular}

4.7. Sanidade de cariopses sem cascas e cascas apös prë-limpeza e limpeza, e de cariopses com pêlo

Os fungos e as unidades infectadas ou não, f으 ram contados, suas porcentagens calculadas, e são apresentados na Tabela 7 . 


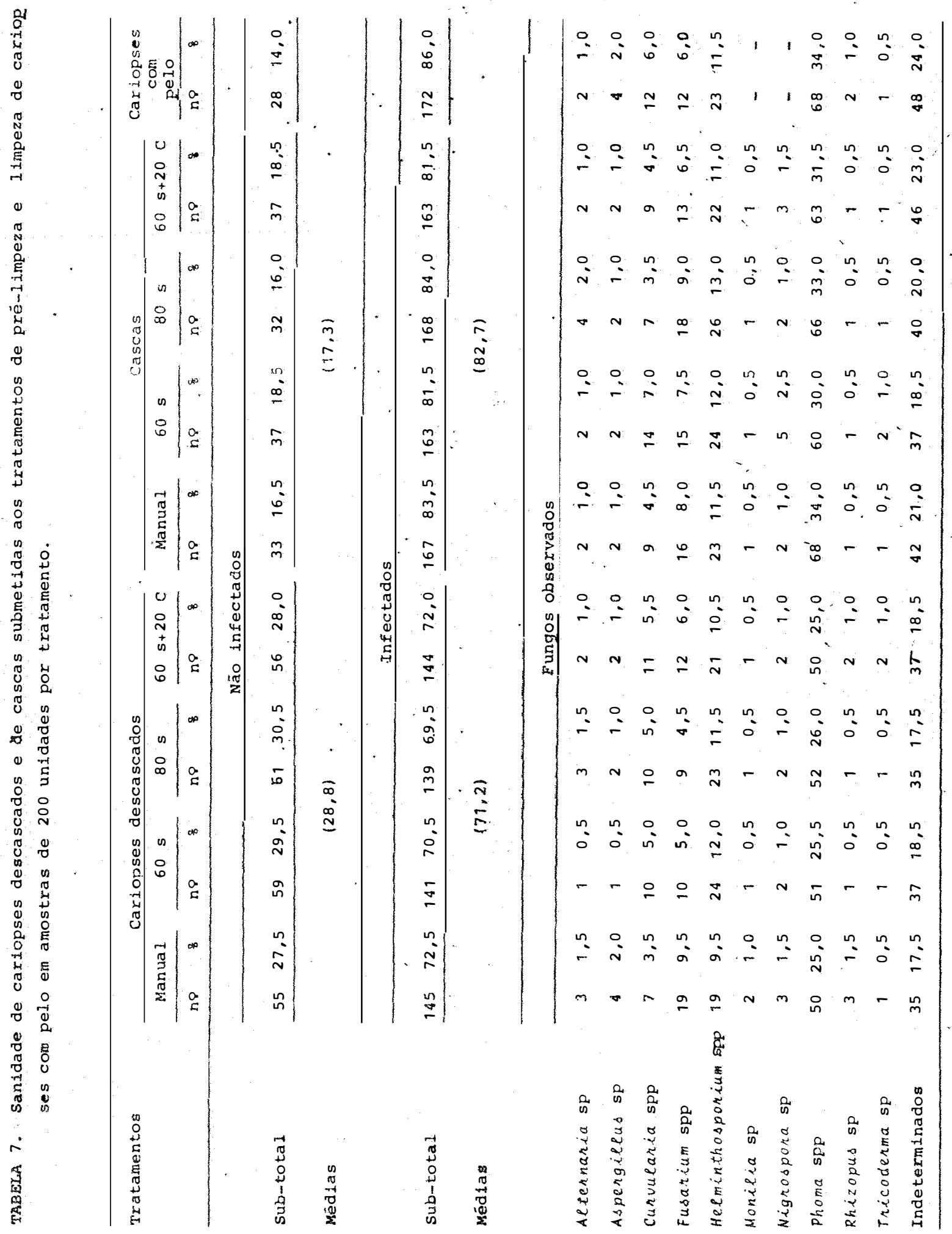


.40 .

\section{PISCUSSÃo}

5.1. Escolha da superfície de fricção complementar

No melhoramento genético da cana-de-açúcar, qualquer plântula oḅtida de um bom cruzamento poderá dar orí gem a um novo cultivar. Principalmente devido a êsse fato, os cuidados devem ser tomados nas operações de processamento para evitar danos aos cariopses.

As operações de pré-limpeza podem eventualmente retirar a pálea e a lema que protegem os frutos e causaṛ perdas de germinação e vigor; fica portanto evidenciado que alguns cuidados devem ser tomados durante as operações de pré-limpeza com a SFC, pois como ficou demonstrado no experimento 3.2., cariopses com teor de umidade ao redor de $7 \%$ são mais sensíveis ao descascamento total do que aqueles cujos teores estão em equilíbrio com o ambiente natural. 
Os resultados experimentais demonstraram tambëm que os tempos de utilização da SFC não devem ser maiores que 20 segundos para minimizar as injúrias aquí comentadas.

5.2. Eficiéncia dos tratamentos de pré-limpeza dos cariop ses determinadas apōs ventilação e avaliadas pela redução de volume

A presença do anel de pêlos na base dos cariopses de cana-de-açúcar torna-os facilmente dissemináveis pelo vento, favorece perdas e misturas do material em semeadura e requer câmaras de estocagem de alto volume chegando a atingir cerca de $20 \mathrm{~m}^{3}$.

Visando eliminar esses incovenientes è que se desenvolveu os equipamentos de pré-limpeza, no intuito de tornar possivel a estocagem do material em congeladores domésticos.

A remoção do anel de pêlos dos cariopses é o principal fator de redução do volume absoluto, conforme SILVA (1974) que encontrou $64 \%$ de redução.

Após a remoção dos pelos, pelos tratamentos e sua correspondente redução, os volumes remanescentes $(36 \%$ aproximadamente) foram novamente reduzidos pela ventilação 
com a eliminação das outras impurezas; obteve-se nova diminuição encontrando-se experimentalmente os valores para os tratamentos manual, $68 \% ; 60 \mathrm{~s}, 65 \% ;$ e $60 \mathrm{~s}+20 \mathrm{C}, 72 \%$. Comparando-se o tratamento manual com $060 . \mathrm{s}+20 \mathrm{C}$, notamos não haver diferença estatistica. Comparando-se os tratamentos ma nual com $60 \mathrm{~s}$ observamos que estes diferem estatisticamente ao nivel de lơ pelo teste de Tukey. Avaliando-se este fato com base no volume e qualidade das parcelas usadas no tratamento manual em comparação com a média obtida anteriormente quando não existia o equipamento mecânico de pré-limpeza, oḅ servou-se que a qualidade do trabalho manual foi muito acima das obtidas nas operações rotineiras anteriores. Reforçam este fato a pequena parcela trabalhada neste experimento, on de fatores como estafa e monotonia näo tiveram influência na qualidade do serviço, alterando os resultados do tratamen to manual para melhor.

Mesmo sem interferir no conjunto de resultados, poderiam ser maiores os percentuais de redução de volume se não tivessemos trabalhado com cariopses de diversos cultivares. 
5.3. Eficiência dos tratamentos de prë-limpeza dos cariop ses determinadas após ventilaçăo e avaliadas pela re duçäo de peso

As reduções em peso encontradas por SILVA (1974) foram de 17\% pela eliminação dos pêlos e as máximas reduções encontradas por BLEICHER (1978) com a ventilação foram de $85 \%$

No exame dos resultados do experimento em questäo encontramos 65: para o manual, 58\% para o 60 s e $68 \%$ para o $60 \mathrm{~s}+20 \mathrm{C}$, que diferem de BLEICHER (1978) por se tratar de cariopses de outros cultivares, porém indicam que houve ganho nessa operação, e as considerações sobre o uso de mistura varietal de cariopses do item anterior são aqui também válidás, pela dificuldade de separação de material he terogeneo pela ventilação. Os tratamentos manual e $60 \mathrm{~s}+$ 20 C foram estatisticamente iguais; o tratamento manual dife riu ao nível de 1\% de probabilidade pelo teste Tukey do tratamento $60 \mathrm{~s}$; neste caso as considerações sobre a qualidade das parcelas e do trabalho manual do item anterior, aquí tam bém se aplicam. 
5.4. Eficiencia dos tratamentos de pré-limpeza dos cariop ses determinadas apōs a ventilaçào e avaliadas pela porcentagem de germinaçäo

Considerando o exposto no início da discussão, injūrias nos cariopses podem causar queda de germinação e vigor. Assim senđo, as operações descritas no presente trabalho de pré-limpeza e limpeza só terão valor agronômi co caso não alterem a germinação e vigor do material original.

O trabalho de SILVA (1974) mostrou também que o processo manưal e mecânico quando comparados aos cariopses com pêlos não causaram queda de germinação e vigor.

A não existência de diferenças estatísticas na análise de variância e Tukey no experimento mostrou que nas amostras trabalhadas não houve interferência na qualidade dos cariopses, eliminando assim a hipótese de possíveis danos que pudessem ser causados à germinação por qualquer um dos tratamentos utilizados. 
5.5. Eficiência dos tratamentos de pré-limpeza dos cariop ses determinadas após a ventilaçào e avaliadas pelo vigor

As considerações expostas no início da discus são e no ỉtem 5.4. referente a germinação, são vãlidas também para este caso.

A não existência de diferenças estatísticas na anảlise de variância e de Tukey no experimento 3.3.4., de monstrou que nas amostras trabalhadas não houve interferência no vigor dos cariopses eliminando assim a hipótese de

- possiveis danos, que pudessem ser causados pelos tratamentos. Estes resultados reforçam os dados obtidos no item 5.4., referente a germinação e indicam melhoria na pureza fí sica dos lotes processados.

5.6. Determinação de rendimento da mäquina de pré-1impeza

De acordo com os resultados comentados na dis cussão, ficou evidente que o equipamento e processo utilizados no trabalho atingiram os objetivos e metas para os quais foram desenvolvidos. Resta-nos porém quantificar os ganhos em tempo de trabalho proporcionado pela pré-limpeza mecânica em comparação com a pré-limpeza manual. 
Analisando os dados apresentados na Tabela 6 expressos em porcengagem, manual $0 \% ; 60 \mathrm{~s}, 86,4 \% ; 60 \mathrm{~s}+$ 20 C, $81,8 \%$, vemos que, mesmo se acrescentassemos 30 segundos aos tempos das operações mecânicas relativos a carga e descarga das câmaras de pré-limpeza, ainda assim teríamos uma redução percentual superior a $80 \%$.

5.7. Sanidade de cariopses sem cascas e cascas após prē- limpeza e limpeza, e de cariopses com pêto

COnforme TOLEDO e MARCOS FILHO (1977) e POPININGIS (1977) a germinação e. o vigor são diretamente proporcionais ao estado de sanidade das sementes de modo geral.

Devido a esse fato, na avaliação dos equipamentos de pré-limpeza e limpeza, é necessārio mensurar as possibilidades dessas operações aumentarem a contaminação e dispersão de inóculos das unidades infectadas para as sadias, pois se isso ocorresse seria um grande inconveniente da tecnologia proposta.

Não foi efetuada análise estatística dos dados coletados devido à contaminação com Neurospora sp. que impediram a correta identificação de muitos gêneros, crescen do a classe dos indeterminados, e por isso preferimos discutir os resultados e tendèncias sem reforço estatístico. 
Assim, apenas para os tratamentos com cariopses cescascadas podemos entender não ter ocorrido diferenças entre eles, porém sempre houve diferenças entre os grupos in fectados e não infectados.

Da mesma forma apenas para os tratamentos com casca podemos entender não ter ocorrido diferenças entre eles, porém sempre houve diferenças entre os grupos infecta dos e não infectados. Também para cariopses com pêlos houve diferenças entre os grupos infectados ou não infectados.

Observamos também nos diferentes grupos de unidade avaliadas, haver uma tendência de niveis de infecção crescente de cariopses sem cascas, aumentando para cascas, e mais ainda para cariposes com pêlos.

Por último, observamos também haver uma semelhança com os gêneros mais comuns descritos.

A influência dos tratamentos de pré-limpeza e limpeza na sanidade dos lotes trabalhados pode ser observada comparando-se qualquer. um dos resultados obtidos com os da sanidade de cariopses com pêlos, que mostram $14 \%$ de não infectados (o menor indice do experimento) e 86\% de infectados (o trator indice do experimento).

Assim, para cascas não infectadas, temos, manua1, $16,5 \% ; 60 \mathrm{~s}, 18,5 \% ; 80 \mathrm{~s}, 16 \%$ e $60 \mathrm{~s}+20 \mathrm{C}, \quad 18,5 \%$, 
que indicam maior número de não infectados.

Para cariopses descascados, temos, manual, $27,5 \circ ; 60 \mathrm{~s}, 29,5 \% ; 80 \mathrm{~s}, 30,5 \%$ e $60 \mathrm{~s}+20 \mathrm{C}, 28 \%$, indices que indicam o dobro de não infectados.

Raciocinio semelhante pode ser feito para a classe dos infectados, cujos resultados são as diferenças da porcentagem.

Pelos resultados obtidos, todos tratamentos tiveram indices superiores de não infectados, o que permite concluir que os tratamentos não provocaram a disseminação dos esporos, e mais ainda, mostram a tendência da diminuição dos Indices de infeç̧ão quando se eliminam cascas e pedúnculos; assim as infecções nos cariopses observados são frutos das condições ambientais da estação de floração que propiciam alta infeç̧ão nos cariopses, o que concordam com TOKESHI (1980); pode-se concordar tambëm com SANGUINO (1974) que encontrou menores níveis de infecções nos cariopeses descascados, quando comparados com os de cascas.

Tambëm podemos notar que a. ocorrência dos gêneros mais comuns concorda com a maioria dos autores que examinaram a sanidade de cariopses de cana-de-açúcar, a excessão de CAZALET e BERJAK (1983). 


\subsection{Discussăo Geral}

Os elevados custos dos programas de melhoramento da cana-de-açúcar estão exigindo melhorias nos métodos de seleção de plantas mais produtivas, adequando-os às exigências industriais e a niveis satisfatórios de resistência às principais doenças. Isto pode ser comprovado pelo grande nümero de clones altamente produtivos que são eliminados após 4 a 6 anos de seleção, quando já entraram nos ensaios de competição com variedades comerciais, e apresentam, pois, custos elevados quando comparados com os de clones nos primeiros estágios de seleção.

Uma das alternativas para reduzir os custos de produção das novas variedades seria a eliminação precoce das plantas suscetíveis às doenças. Objetivando atingir esta meta os autores DUARTE (1976), SILVA (1978), BLEICHER (1978), SANGUINO (1976), DIAS (1981), desenvolveram trabalhos de pesquisa para adequar uma metodologia de seleção pre coce de plantas resistentes ao carvão da cana-de-açúcar e à mancha ocular.

Todas aquelas pesquisas esbarraram na mả qualidade dos cariopses e demonstraram que o sucesso dos novos métodos de seleção precoce dependem da qualidade dos cariopses. Cariopses de má qualidade interferiram nos métodos de seleção precoce nos seguintes pontos: 
a. baixo Indice de germinação;

b. aumento de mortalidade de plântulas inoculadas devido ao baixo vigor;

c. mascaramento da eficiência de seleção devido a morte prematura de plântulas suscetiveis ao carvão;

d. interferência dos microorganismos que acompanham as impurezas dos cariopses na germinação, e colonização de plântulas inoculadas precocemente;

e. Redução do período de armazenamento dos cariopses. Em de corrência do exposto, ocorrem falhas nas inoculações precoces, impedindo a seleção precoce por tornarem-nas erráticas.

Deduz-se que a aplicabilidade dos métodos de seleção precoce de plantas resistentes ao carvão da cana-de-açúcar está na dependência da produção de cariopses de elevado vigor, no controle dos patógenos que infectam os cariop ses nos estágios finais de maturação e na melhoria dos processos de pré-limpeza e limpeza dos cariopses obtidos nos cruzamentos.

O presente trabalho concentra os esforços nes te último item e indica avanços substanciais no processo de beneficiamento parcial dos cariopses da cana-de-açúcar. Os resultados advindos da associação do deslintamento desenvolvidos por SILVA (1974) com a ventilação forçada estudada por BLEICHER (1978) possibilitam a eleminação de 17\% do peso de 
impurezas no deslintamento e de 50 a $60 \%$ do peso de impurezas pela ventilação. Estas duas operações totalizam a elimi nação aproximada de 67 a 77\% das impurezas que acompanham os cariopses férteis da cana-de-açúcar.

Pelos resultados apresentados no presente tra balho verifica-se que com a melhoria dos equipamentos de pré-limpeza os seus rendimentos permitiram a redução do tempo de trabalho em torno de $80 \%$ em relação a pré-limpeza manual. A introdução da superfície plástica complementando a ação do tapete de nylon desenvolvido por SILVA (1974) tem permitido a remoção de grande parte dos pedúnculos que acompanham os cariopses férteis. Esta remoção de pedúnculos prô porcionou a eliminação de $72 \%$ das impurezas remanescentes.

A eliminação das impurezas dos lotes traz melhorias substanciais nos métodos de seleção precoce de plantas resistentes ao carvão porque é nelas que se alojam grande parte dos fungos contaminantes dos cariopses.

As contagens de patógenos das cascas dos cariopses ainda indicam que o problema não está solucionado e que modificações substanciais na metodologia de produção de cariopses terão que ser introduzidas nas estações de cruzamentos até que estas dificuldades seja minimizadas.

A utilização de meios mecânicos de beneficią mento de sementes sempre suscita dúvidas quando à ocorrência 
de misturas de lotes ou cruzamentos diferentes. Os equipamentos descritos neste trabalho, com um mínimo de atenção do operador anulam esta possibilidade, sendo altamente confiável.

Pelos benefícios que proporcionam, o programa de melhoramento genético do IAA-PLANALSUCAR adotou, e utiliza desde 1981 os métodos e processos descritos no presente trabalho. Da experiência acumulada e dós resultados obtidos nos últimos 3 anos, procuramos sumarizar a seguir os beneficios diretos e indiretos observados, e estimados a quantificação dos ganhos, visto que muitos parâmetros avaliados são de difícil mensuração.

com o material assim processado, tem-se gasto para a gexminação das plântulas, $70 \%$ a menos nos seguintes itens: volume do substrato orgânico, nümero de caixas, ärea apropriada ou casa de vegetação, fumigantes de solo, etiquetas de identificação, e, mão-de-obra ou tempo nas operações de semeadura, irrigações, pulverizações e outros cuidados, alëm de 70\% a menos de folhas na germinação.

Também houve uma redução de $60 \%$ na programação de trabalho para a obtenção de plântulas e na programação de trabalho para a inoculação de trabalho para a inocula ção precoce de mosaico. Ainda também, deixam de ser necessá rias as câmaras frias de alvenaria, e grande tambores utili- 
zados para embalagem, viabilizando o uso de práticos, precisos e bem menos dispendiosos congeladores domésticos utiliza dos para o armazenamento.

Ficam também diminuidos em 70 \% o volume e peso do material a ser armazenado, a ser transportado para as demais coordenadorias do IAA-PLANALSUCAR, e os custos de transporte aéreo.

As reduções de volume, pèso e patógenos, permitiram melhorias nas condições de armazenamento e viabilizą ram a época de novembro para a obtenção de plântulas, utilizada com êxito na coordenadoria nordeste do IAA-PLANALSUCAR. Permitirão ainda, mediante técnicas sofisticadas de armazena mento, a reutilização de cruzamentos a muito armazenados e estudados, viabilizando assim a reutilização do restante de material daqueles cruzamentos que apresentarem resultados ou clones mais promissores. Na Tabela 8, procura-se sumarizar os benefícios observados e estimativas da sua quantifica ção conforme considerações do texto. 
TABELA 8. Benefícios obtidos e estimativas de reduções alcan çados com a adoção da pré-limpeza e limpeza de cariopses de cana-de-açúcar no IAA-PLANALSUCAR.

Atividade e material

Estimativa de reduções

$\left(\frac{\circ}{\circ}\right)$

Solo orgânico para germinação

Caixas de germinação

Area de casa de vegetação para germinação

70

Etiquetas de identificação

70

Tempo de semeadura

70

Fumigantes de solo

70

Aplicação de tungicidas

70

Falhas na germinação

70

Mão-de-obra na germinação

70

Programação de trabalho na obtenção de plântulas

60

programação de trabalho na inoculação precoce de mosaico

Substituição de câmaras frigoríficas por congela dores domésticos

Volume de material armazenado

Volume do material transportado

Custos de transporte

Substituição dos grandes tambores de armazenamen to por embalagens mais präticas 


\section{CONCLUSÕES}

Dos resultados e discussões apresentados as seguintes conclusões mais relevantes foram obtidas:

a. as operações de prë-limpeza e limpeza de cariopses de cana-de-açūcar utilizados nos programas de melhoramento prô porcionam economias substanciais no armazenamento dos cariopses e nos custos de obtenção de plântulas;

b. as reduções do volume de cariopses a serem armazenados possibilitaram a substituiçăo de dispendiosas câmaras frí gorificas de volume aproximado a $20 \mathrm{~m}^{3}$ por econômicos con geladores domésticos de $0,5 \mathrm{~m}^{3}$.

c. a elevação da pureza física dos cariopses assim obtidos 
poderá aproximar os programas de seleção precoce para resistência ao carvão da cana-de-açücar aos altos níveis ob tidos experimentalmente;

d. os equipamentos em uso no programa de melhoramento genētí co do IAA-PLANALSUCAR são eficientes pois a avaliação glo bal de germinação, vigor e sanidade dos cariopses trabalhados não evidenciou injūrias nos mesmos, proporcionando somente beneficios;

e. o controle do teor de umidade dos cariopses que receberão prë-limpeza com superfície de fricção complementar deve ser efetuado com precisão para evitar os danos mecânicos. 


\section{Literatura Citada}

ARTSCHWAGER, E., E.W. BRANDES e R.C. STARRET, 1929.

Development of flower and seed of some varieties of sugar cane. Journal of Agricultural Research, Washington, 30: $1-30$.

BARNETT, H.L. e B.B. HUNTER; 1972. Ilustrated genera of imperfect fungi. 3 a ed. Minneapolis, Burgess Publishing Caompani. 241 p.

BLEICHER, J., 1978. Efeito da ventilação na germinação de cariopses e do vácuo na inoculação de llstilago scitaminea em cana-de-açücar. Piracicaba, ESALQ/USP, 64 p. (Tese de Mestrado).

BYRD, H.W., 1967. Seed technology handbook. Jacarezinho, PR. Sementes Agroceres. 46 p. (mimeografado). 
BYTHER, R.S. e G.W. STEINER, 1972. Four sugarcane seedling diseases in Hawail: causal agents, control, and a seletive medium for isolation. Phytopathology, Lancaster,

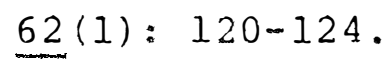

CAZALET; R.K. e BERJAK, 1983. Isolation of a seed storage fungus from sugarcane seeds. Proceedings the South African Sugar Technologists Association. 1-4.

DIAS, A.S., 198] Influência do văcuo, fotoperiodo e substrato na seleção de cana-de-açúcar resistente a llstilago scitaminea. Piracicaba, ESALQ/USP, 65 p. (Tese de Douto rado).

DUARTE, M.L.R., 1976. Padronização metedológica da inoculação de plântulas de cana-de-açúcar para seleção de resistência a Ustilado scitaminea. Piracicaba, ESALQ/USP. 67 p. (Tese de Doutorado).

DUARTE, M. de L.R. e H. TOKESHI, 1978. Inoculation of sugarcane seedlings for selection of resistance to Ustilago scitaminea Sya. "in vitro". Summa Phytopathologica, Piracicaba, 4: 33-100.

JUSTICE, O.L. e L.N. BASS, 1978. Principles and practices of seed storage. Agriculture handbook no 506. United States Department of Agriculture, Washington, $289 \mathrm{p}$. 
LYRENE, P.M., 1976. A method for dehulling sugarcane caryopses. sugareane Breeders' New Letter. 37: 47-48.

MARCOS FILHO, J., S.M. CICERO e F.F. de TOLEDO, 1983. Manual de Análise de Sementes. Departamento de Agricultura e Horticultura, ESALQ, Piracicaba, 112 p. lapostila mimeografada).

PEERUN, Z., R. HERMELIN e J.A. LALQUETTE, 1978. A method for degluming sugarcane caryopses. Sugarcane Breeders' News Letter, 41: 4-7.

POPINIGIS, F., 1977. Fisiologia da semente. AGIPLAN, Brasi lia, 289 p.

SANGUINO, A., 1976. Patologia e controle dos fungos de sementes de cana-de-açúcar e resistência de progênie à Helminthosporium sachari. Piracicaba, ESALQ/USP. 77 p. (Tese de Mestrado).

SILVA, W.M., 1974. Produção de "seedlings" de cana-de-açücar pelo beneficiamento do "fuzz" e transplante precoce. Viçosa, UFV. 34 p. (Tese de Mestrado).

SILVA, W.M., 1977. Production of sugarcane seedlings by the method of fuzz processing and early transplantation. Proceedings of the XVI Congress, ISSCT, 1977. VI, p. $165-176$. 
SILVA, W.M., 1978. Pré-seleção de "seedlings" de cana-de-açúcar resistentes a ustilago scitaminea, pela inoculação das sementes sexuais. Piracicaba, ESALQ/UPS, 65 p. ( $T$ ese de doutorado).

STEVENSON, G.C., 1965. Genetics and breeding of sugarcane. 1. edição. Printed in Great Britain by Butter \& Tanner Ltda., Frome and London. $284 \mathrm{p}$.

TOKESHI, H., 1980. Doenças da cana-de-açúcar. In: GALLI, F., Coord. Manual de Fitopatologia: doencas das plantas cultivadas. 2a ed. São Paulo, Editora Agronômica Ceres, v. 2 , p. $141-206$.

TOLEDO, F.F. e J. MARCOS FILHO, 1977. Manual das sementes: tecnologia da produção. Ed. Agronômica Ceres, São Paulo. $224 \mathrm{p}$. 